UDC 378.22

I. Petrenko, Cand. Sc. (Polit.), Assoc. Prof., orcid.org/0000-0003-3328-4102,

G. Malkina, Dr. Sc. (Polit.), Assoc. Prof., orcid.org/0000-0002-2307-4702,

V. Kolyukh, Dr. Sc. (Polit.), Assoc. Prof., orcid.org/0000-0002-8545-7450

\title{
MANAGEMENT FEATURES OF MODERN THINK TANKS
}

Purpose. To find the reasons for the insignificant influence of Ukrainian think tanks on the development of the state structure of Ukraine, as well as to develop a new management strategy for Ukrainian think tanks to increase their importance in formation of political thinking and state policy of Ukraine.

Methodology. The authors used the system-structural, structural-functional methods, as well as methods of comparison, analysis, synthesis, and expert evaluation.

Findings. The authors reviewed the development of think tanks in the history of world culture and found three main features: 1) the influence of think tanks on political thinking and public policy is carried out indirectly through individuals who make political decisions; 2 ) the management of the think tank is the ability to work with gifted people who generate political innovations (policy innovation); 3) the think tank management is the highest perfection of the policy of entrepreneurship, which allows embodying political innovations in the state policy. The authors considered the management of the Ukrainian think tank and established its discrepancy to the world standards. The management of Ukrainian think tanks specializes mainly in analyzing problems and recommendations for solving them, whereas management of the leading world think tanks is aimed at the embodiment of political innovations in political decisions. The authors have proposed a new management strategy for the Ukrainian think tanks, which is based on rethinking attitude towards 1) human resources; 2) material resources; 3) information resources; 4) reputational resources.

Originality. The authors have proved that the management of Ukrainian think tanks is inconsistent with the standards of the world's leading think tanks. The Ukrainian think tank focuses on analyzing the problem, while the management of the world's leading think tank embodies political innovation in political decisions.

The authors have worked out the new management strategy for the Ukrainian think tank. It is based on rethinking of four key resources: 1) the human ones; 2) the material ones; 3) the informational ones; 4) the reputational ones.

Practical value. Using the results obtained in the course of the research will increase the effectiveness of Ukrainian think tanks. The authors believe that the new strategy of management will help Ukrainian think tanks to attract gifted scientists who are able to generate innovative political strategies, as well as gifted managers who will bring political innovations to officials, politicians and political parties. The management directed to generation of political innovations and their embodiment in the state policy will allow Ukrainian think tanks to occupy an important niche in development of the Ukrainian State system.

Keywords: think tanks, management, Ukrainian political elite, political thinking

Introduction. The term "think tank" (analytical center) was included into a scientific use after World War II. It contained the meanings, the history of which originated approximately in the 16th century. [1]. Just since those times, as considers Jacob Soll, the idea "that serious and focused research groups could solve the world's wicked problems" occurred [1]. The illustrative examples of impressive opportunities of the think tank are achievements of the well-known Brookings Institution in the U.S. and the Institute for Economic Affairs in Britain. In spite of the fact that these analytical centers work irrespective of the governments, for the history of their existence they have had a considerable impact on political thinking and state policy of the USA and Great Britain. [2].

The most part of the world-famous think tanks appeared in 1970-1980, as a result of the end of the Cold War and the beginning of globalization.

In modern understanding, the term "think tank" means a research institute, center or organization that

(C) Petrenko I., Malkina G., Kolyukh V., 2019 explores and lobbies the results of its research on questions of social policy, development strategies of the state, economy, war, technology and culture.

The main feature of the "think tank" is that for the most part they are non-profit organizations. For example, in the United States and Canada, they are granted tax-free status (tax exempt status). In other states, including Ukraine, think tanks are funded by governments, human rights groups, or large corporations. The main source of income for commercial think tanks is consulting and research works.

In Ukraine now, there are more than 100 think tanks. The most known think tanks are:

1. Centre of Policy and Legal Reform (CPLR), which was created in 1996 [3].

2. Razumkov Centre, which was registered on August 15, 1994.

Despite the seemingly impressive number of think tanks in Ukraine, their influence on the formation of political thinking and public policy is insignificant. The niche of the think tanks in the state structure of Ukraine, 
in comparison with the activity and influence of the think tanks in the states of the European Union, continues to remain free.

In this article, the authors will examine the reasons for the insignificant influence of the Ukrainian think tanks on the development of the state structure of Ukraine, and also suggest the management strategy for the Ukrainian think tanks based on the experience of the leading think tanks in the world.

Presentation of the main research. A sufficient number of articles have been written about the need for integration of Ukraine into the European community and the use of the experience of highly developed countries of the world in the development of state institutions of power and public organizations. It is worth marking out the works of S. Rudenko with his coauthors [5], R. Naumenko [6], S. Terepyshchyi [7], and others. On March 21, 2014 and on June 27, 2014, Ukraine signed a political and economic part of Association Agreement between Ukraine and the EU [8]. In these documents, the final vector of the strategic development of the Ukrainian state system is fixed.

Political thinking and state policy are formed by a number of factors. The important value in this process belongs to think tanks. However, unlike the advanced democratic states, the Ukrainian think tanks have the nominal power, as understood by D. Svyrydenko and O. Yatsenko [9]. In order to allow them to reach the real power and occupy their niche in the complex state mechanism, it is necessary to adapt the management experience of the think tanks of the leading countries of the world for the Ukrainian reality.

Let us consider the main features of the think tanks, which allow them to show the real power and to have a direct impact on the domestic and foreign policy of the leading states of the world. Key features of any problem are visually shown in the history of culture, for example [10]. Considering the development of think tanks in the history of world culture, the authors found three main features:

1. Essentially, think tanks do not have a direct impact on policy, since they do not participate in the details of the implementation of public policy and in the formal policy-making process. However, think tanks interact with political decision makers: high-ranking government officials, politicians and political parties. The influence of think tanks on political thinking and public policy is carried out indirectly.

2. The significance of think tanks is determined by the ability to resolve key issues of social policy, political strategy, economics, etc. promptly, i.e., it is primarily the ability to organize and manage a team of scientists, high-level researchers. The think tank is not just corporate governance; it is the management of gifted people who generate policy innovation.

3. Generation of political innovations of think tanks is an important feature, yet not the only one which is traced in the history of culture. No less important feature of think tanks is the ability to extend political innovations among the political elite, to achieve their embodiment in the state policy. This quality requires the highest perfection of policy entrepreneurship from the think tank management. Indeed, on the one hand, the think tank management should provide motivation for gifted people; on the other hand, the think tank interaction with officials, politicians and political parties; in the third aspect, the think tank interaction with society, the ability to influence on public opinion.

Three main features of think tanks, established by us, allow us to proceed to the performance of the main tasks of this work. Namely,

1. To consider compliance of the Ukrainian think tanks with the international standards.

2. To offer the strategy of management of the Ukrainian think tanks.

Let us consider the first task: compliance of the Ukrainian think tanks with the international standards. The authors analyzed compliance of the Ukrainian think tanks with the think tank standards of the Carnegie Endowment for International Peace level (United States, founded in 1910), Brookings Institution (United States, founded in 1916), Chatham House (UK, founded in 1920), French Institute of International Relations (France, founded in 1979).

As a result of the analysis, the authors came to the following conclusion: between the terms "think tank", which is used in the English-speaking environment (and not only), and the term "analytical centers", which is used in the Russian-speaking environment, the meanings of which have been transferred to the Ukrainian language, the essential differences are traced. In essence, these terms are not synonyms, though the term "think tanks" is translated traditionally as "analytical centers". In The Cambridge Dictionary, which is published by Cambridge University Press, the British and American definitions of the term "think tank" are given. In the first case, it is "a group of experts brought together, usually by a government, to develop ideas on a particular subject and to make suggestions for action" [11]. In the American understanding, the term "think tank" means, "an organization whose work is to study specific problems and suggest solutions, often with a particular political view" [11]. That is, primarily, it is a study of a specific problem and its solution.

The authors have analyzed the websites of some of the most authoritative think tanks in the world, such as Carnegie Endowment for International Peace [12] and Brookings Institution [13]. It was revealed that work reports of these think tanks can be divided conditionally into two parts:

a) formulation of the problem and its comprehensive analysis;

b) ways of solving the problem and the achieved final result.

Thus, in essence, think tanks work on the analysis of a problem and its decision. It is not only a science, but it is management as well. A part of employees of think tanks are researchers of the high level who know perfectly the scientific methods of the analysis. Another part is the staff of high-level managers who embody the obtained scientific results in practice, i.e. bring to the end result. 
If we compare meanings of the term "think tank" to meanings of the term "analytical centers", then the main difference consists in the following: the "analytical centers", as such, according to the meanings are closer to a phrase "expert analytical centers". In the Ukrainianlanguage scientific literature, these two terms are used as synonyms. Both terms mean, first of all, expert assessment of a problem and recommendations. The authors have analyzed the reports of the leading Ukrainian "analytical centers" that position themselves as "think tanks": the Center of Policy and Legal Reforms (CPLR) and Razumkov Center. These reports are posted on the websites of these organizations [3, 4]. The emphasis in these reports is placed on the analysis of a problem and recommendations as for its decision. The achievement of the end result is not mentioned in the reports mainly.

Certainly, this key difference between management of the leading world think tanks and the Ukrainian "analytical centers", which position themselves as think tanks, can be explained. In the Ukrainian political thinking and public administration, the post-communist syndrome dominates.

In the article "The Incidence of Traditionalists, Skeptics, Democrats, and Radicals", the authors explored the countries of the former Soviet Union: Russia, Moldova, Ukraine, as well as the Baltic states. As a result of the research, M. Klicperova-Baker and J. Kostal have established that democratic values in these states prevail mainly among young people. However, they make up the minority on a scale of all population. In the countries of the post-Soviet period, the categories of the population that the authors have designated by the terms "intolerant traditionalists" and "passive skeptics" are brightly and powerfully represented. Just these very categories of the population continue to defend furiously the advantage of the totalitarian (or authoritative) regimes, or to treat democratic innovations with skepticism. These particular psychological aims at "the better life in the past" are called the "post-communist syndrome" by the authors [14].

Transition of "scientific communism" to the Ukrainian political thinking and state policy, is considered in article "Scientific Communism" and the Modern Political Science in Ukraine [15]. The author actually states the presence of a post-communist syndrome in thinking of the Ukrainian political elite and, respectively, in public administration.

The authors believe that the prevalence of "intolerant traditionalists" and "passive skeptics" in thinking of Ukrainian officials and politicians is the main reason for the lack of the clearly defined development strategy of the state and institutions of state power. The same reason, in essence, makes it impossible for the Ukrainian think tanks to find the real political power, and to achieve that influence which the world's leading think tanks have. In the modern Ukrainian policy, the think tanks are assigned as the analytical and advisory centers. Political decisions were accepted and continue to be accepted in the authoritative style.

To change the existing state of affairs and open access for the Ukrainian think tanks to decision-making, a new management strategy is required. Besides emphases on the embodiment of political innovations in political decisions, this strategy means, among other things, influence of the Ukrainian think tanks on formation of a new political elite. For example, in the article "The Image of an Ideal Ukrainian Politician. Ukrainian National Idea" the sequence of formation of the image of a new ideal Ukrainian politician is considered [16]. In the article De-Communization of Childhood by the Polish researcher P. Walczak, the ways of decommunization of the society, or overcoming a post-communist syndrome are considered after the example of Poland [17]. In essence, think tanks play an important role in all these processes.

Let us consider the second task of our research: offering the strategy of management of the Ukrainian think tanks that will allow them to achieve the significance of the think tanks of the leading countries of the world.

The authors suggest reconsidering the relation to resources which think tanks have. First of all, to reconsider the relation to: 1) human resources; 2) material resources; 3) information resources; 4) reputational resources. Let us consider these four directions of strategy of management of the Ukrainian think tanks in detail.

1. Human resource of think tanks. Considering the development of think tanks in the history of world culture, we have already paid our attention to the fact that the main feature of think tanks is the human resource, namely, work with gifted people. These are gifted scientists and researchers who can think in a non-standard way, and gifted administrators who establish close communication with high-ranking government officials, politicians and political parties. Comparing the Ukrainian and leading world think tanks, the authors found the difference in relation to human resources: to the individual work with employees and the assessment of their labor. This difference is most clearly seen in the annual reports that are presented on the websites of think tanks. For example, reports of Carnegie Endowment for International Peace [12] and Brookings Institution [13] were personalized. Their analysis allows us to get a particular idea of who exactly worked on the problem and what contribution was made for its solution. If we analyze the reports of the Ukrainian think tanks, we can see that they are compiled primarily on behalf of the organization. For example, from the progress report for 2017, which is presented on the website of the Centre of Policy and Legal Reforms (CPLR) [3], we will not be able to identify the exact performers. The report is compiled on behalf of CPLR, the abbreviation of the name of the Centre.

In our opinion, the concealment of the individual contribution in collective labor is a clear example of the "post-communist syndrome". In the management of the Ukrainian think tanks, disrespect for specific performers and the underestimation of the importance of individual labor are seen distinctly. The lack of personalization in the performance of a specific task eliminates the importance of a human resource and reduces the potential of the Ukrainian think tanks. Such attitude, in fact, blocks access to the think tanks for gifted people 
who are able to generate policy innovations and embody them in political decisions, into actions. Gifted people will not want to lose the identity behind an abbreviation even of the famous Carnegie Endowment for International Peace, Brookings Institution and others.

In the new management strategy, we propose to revise the attitude to human resources. It is necessary to personalize the work of the Ukrainian think tanks, thereby ensuring the involvement of gifted scientists and administrators. The merits and authority of scientists and administrators form the authority of the think tanks. As a result, the degree of influence of the think tanks on the formation of political thinking and public policy is increasing. The think tank turns into a generator of ideas and the embodiment of new ideas into political decisions.

2. Material resource of think tanks. Essentially, funding sources determine a basis of strategy of management of think tanks. Depending on the funding sources, think tanks can be divided into:

a) university think tanks, which enlist students, graduates and university teachers of various specialties: sociologists, political scientists, managers, and others to solve the objectives;

b) those created by the government and financed by the state;

c) those created or connected with business;

d) those created by political parties and financed from their budget;

e) independent think tanks, created as non-profit organizations.

The material think tank resource is important for motivation of personnel and increase in productivity of the think tank.

If we compare reports for 2017, for example, by Brookings Institution [13] and the Center of Policy and Legal Reforms (CPLR) [3], we will see that in the first case the annual budget made 524.2 million dollars, in the second -752707 dollars. As we see, the budget of one of the best American think tanks exceeds the annual budget of one of the authoritative Ukrainian think tanks almost by 700 times. This difference, certainly, influences the scale and quality of the carried-out tasks.

However, we consider that Ukrainian think tanks have much to develop in this direction. Expansion of the studied problems, the achieved results, and also the authority of the Ukrainian experts, and the involved experts from other states, in general, increase competitiveness of the Ukrainian think tanks not only in the internal market, but also in the international one. The competition for resources of the governments, corporations and private donations, has to become one of the constituents of the new strategy of think tank management.

3. Information resource of think tanks. For think tanks, the work with information and also quick access to the latest information are the important conditions of the high-quality work and competition. The more qualitative information is used in work of think tanks, the more effective is generation of the political ideas and their embodiment in state policy.

It is possible to take the experience of Carnegie Endowment for International Peace (CEIP), for example, as a basis of new strategy of management of the Ukrainian think tanks. Before reaching the level of one of three most authoritative and most influential think tanks in the world, Carnegie Endowment for International Peace created the network of quick access to information. Now this information network covers all continents of the planet.

Firstly, in the first decades of its history, Carnegie Endowment for International Peace was engaged in curator activities and creation of libraries. Between 1883-1929, 2509 Carnegie Libraries were created around the world. These libraries are still maintained and completed by the Foundation. Secondly, in 1923, Carnegie Endowment for International Peace (CEIP) opened officially The Hague Academy of International Law. Among the graduates of this academy were Boutros Boutros-Ghali, the sixth General Secretary of the Organization of United Nations (UN) (January 1992 - December 1996); heads of states and governments; 13 judges of the International Court of Justice; and others. Thirdly, Carnegie Endowment for International Peace in different periods opened its offices in Moscow (in 1994), Beirut (in 2006), Brussels (in 2007), Pekin (in 2010), New Delhi (in 2016). It covered key points of the global world, providing prompt access to information. Fourthly, from 1978 to 2008 Carnegie Endowment for International Peace was the owner of the authoritative political world magazine Foreign Policy, which elucidated the key events of the globalized world. Fifthly, Carnegie Endowment for International became the owner or one of the founders of Peterson Institute for International Economics (1981); Henry L. Stimson Center (1989); Migration Policy Institute (MPI) (2000); and others. All of the organizations listed above are leading think tanks in the narrow areas now: economics, migration policy, nuclear research, etc. Sixthly, at present Carnegie Endowment for International Peace have more than 100 experts who work and live in 20 states.

Thus, the management strategy of Carnegie Endowment for International Peace from the outset was not limited by solving the local problems on the American continent. It was aimed at covering key areas of the international policy research. Its employees and graduates occupied and occupy now the key political positions in the leading international organizations.

Such strategy of management allowed Carnegie Endowment for International Peace not only to get quick access to all information resources, but also to influence directly political decisions on a global scale. The strategy of management has turned Carnegie Endowment for International Peace into the key player of the international policy. By its influence on officials and politicians of the leading states of the world and the international organizations, Carnegie Endowment for International provided the embodiment of political innovations of its own experts in political decisions, which transform the world.

The analysis of information resources of the Ukrainian think tanks finds inaccuracy of the chosen strategy of their management. This strategy is initially limited to problems and needs of Ukraine. For example, Razum- 
kov Center, despite its long history (since 1994), and high authority among the European think tanks, specializes only in the research of state policy. Management of the Center does not overstep the bounds of Ukraine and does not try to create its own information network. However, in our opinion, in the era of globalization, even the features of national political thinking are revealed more while being researched from outside.

The new strategy of management of the Ukrainian think tanks assumes greater use of opportunities of universities and Academy of Sciences of Ukraine. It is necessary to unite with the leading think tanks of the states that Ukraine borders on. It is necessary to work out the solution of the burning problems, which are connected not only with development of Ukraine, but Poland, the Baltic states, Hungary, Romania, Slovakia as well. Creation of our own information network is required both in Ukraine, on the basis of the leading regional universities, and outside its national territory. This network will provide not only access to information, but also to particular policy making at the international level.

4. Reputational resource of think tanks. As we have already noted, reputation of an employee of the think tank raises the reputation of the think tank as well. In its turn, the reputation of think tank attracts investments and the possibility of participation in various international projects. This interrelation between reputation of employees and the organization provides permanent development of the authority of the think tank region-wide and worldwide. Therefore, it may be no accident that the high-ranking officials of the U.S. Administration at different times held and hold the key posts in the leading American think tanks. For example, William J. Burns, who has been the president of Carnegie Endowment for International Peace since February 2015 spent more than 30 years on diplomatic service in the USA, and from 2011 to 2014 was the Deputy Secretary of the USA. John R. Allen, who has been the president of the Brookings Institution since November 2017, is the former commander of NATO International Security Assistance Force and the USA in Afghanistan. He was the senior adviser to the US Secretary of Defense for Security in the Middle East. He held other key positions in administration of U.S. President.

The reputation of top-managers of the think tank provides reputation of the think tank and its opportunity to communicate with the high-ranking officials and politicians both at the level of the state, and at the international level.

Management of the Ukrainian think tanks considerably lags behind in this question. For example, Igor Koliushko, the founder and the chairman of the board of the Center of political and legal reforms has never occupied the high state posts and represented Ukraine at the international level [3]. Pavlo Pinzenik, who is the head of the Razumkov Center now, being 42 years old has never worked in public service and represented Ukraine at the international level [4]. Besides, checking the page of the website of Razumkov Cente "Governing bodies", we will see surnames of people, who are being prosecuted for corruption in European countries.
The new strategy of management of the Ukrainian think tanks is directed to engagement to work of those heads and experts who have versatile international relations and faultless reputation at the international level. We maintain the national identity as an important factor of investigation of society [18]. However, there are international standards, which define the extent of influence of think tanks at the state and international levels. These standards allow think tanks to take the important place in formation of the national political thinking and state policy. Therefore, the real power of think tanks is defined by reputation of their heads and employees. The higher reputation is, respectively, more opportunities for cooperation and investments open up before the think tanks.

Conclusions. Thus, the authors examined the reasons of the insignificant influence of the Ukrainian think tanks on the development of the state structure of Ukraine. The authors believe that the main reason is the specialization of the Ukrainian think tanks in analyzing the problem, while the world leading think tanks accentuate the embodiment of political innovations in political decisions.

The authors have proposed a new management strategy for the Ukrainian think tanks, which is based on the experience of leading think tanks in the world. It is based on the rethinking of the attitude to the resources of the think tanks: 1) human resources; 2) material resources; 3) information resources; and 4) reputational resources.

The authors are convinced that the new think tank management strategy in Ukraine will provide them with access to the international projects and international investments. It will lead to increase in the real power of the Ukrainian think tanks and ensure their influence on the political thinking and government policy.

\section{References.}

1. Soll, J., 2017. How Think Tanks Became Engines of Royal Propaganda. Tablet Magazine [online]. Available at: <https://www.tabletmag.com/jewish-news-and-politics/222421/think-tanks-jacob-soll-propaganda> [Accessed 4 December 2017].

2. Stone, D., 2013. Capturing the Political Imagination: Think Tanks and the Policy Process. Routledge, 2013.

3. Centre of Policy and Legal Reform. 2018 [online]. Available at: <http://www.pravo.org.ua/en/ > [Accessed 27 January 2018].

4. Razumkov Centre. 2018 [online]. Available at: <http:// razumkov.org.ua/en/> [Accessed 12 November 2018].

5. Rudenko, S., Sapenko, R., Bazaluk, O. and Tytarenko, V., 2018. Management Features of International Educational Projects between Universities of Poland and Ukraine. Naukovyi Visnyk Natsionalnoho Hirnychoho Universytetu, 2, pp. 142-147. DOI: 10.29202/nvngu/2018-2/21. 6. Naumenko, R., 2018. Philosophy of Public Governance: Manpower Policy of Modern Ukraine in the Context of Globalization. Philosophy and Cosmology, 20, pp. 106-112. DOI: 10.29202/phil-cosm/20/9.

7. Bazaluk, O., Svyrydenko, D. and Terepyshchyi, S., 2017. Structural-Functional Models of Integration and 
Reintegration of Ukrainian Educational Landscape. Naukovyi Visnyk Natsionalnoho Hirnychoho Universytetu, 5, pp. 163-168.

8. Ministry of Foreign Affairs of Ukraine, 2018. The EUUkraine Association Agreement [online]. Available at: $<$ https://mfa.gov.ua/ua/about-ukraine/european-integration/ua-eu-association $>$ [Accessed 23 December 2018].

9. Svyrydenko, D. and Yatsenko, O., 2018. Dialectics of Nominal and Real Power in the Ukrainian and World Politics. Ukrainian Policymaker, 2, pp. 33-40. DOI: 10.29202/up/2/5.

10. Bazaluk, O., 2017. Plato's and Isocrates' Traditions in the Development of Educational Theories in the History of Culture. Annals of the University of Craiova Philosophy Series, 40 (2/2017), pp. 5-18.

11. The Cambridge Dictionary, 2018. Cambridge: Cambridge University Press [online]. Available at: <https:// dictionary.cambridge.org/ $>$ [Accessed 14 December 2018].

12. Carnegie Endowment for International Peace, 2018 [online]. Available at: <https://carnegieendowment. org/> [Accessed 22 November 2018].

13. Brookings Institution, 2018 [online]. Available at: $<$ https://www.brookings.edu/> [Accessed 7 December 2018].

14. Klicperova-Baker, M. and Kostal, J., 2018. Democratic Values in the Post-Communist Region: The Incidence of Traditionalists, Skeptics, Democrats, and Radicals. Changing Values and Identities in the Post-Communist World, Springer: Cham, pp 27-51. DOI: 10.1007/978-3-319-72616-8_2.

15. Vilkov, V., 2018. "Scientific Communism" and the Modern Political Science in Ukraine. Ukrainian Policymaker, 2, pp. 48-55. DOI: 10.29202/up/2/7.

16. Bazaluk, O. and Blazhevych, T., 2016. The Image of an Ideal Ukrainian Politician. Ukrainian National Idea. Future Human Image, 3(6), pp. 24-30.

17. Walczak, P., 2018. De-Communization of Childhood. Introduction to Research on Transformations of the Discourse on Child and Childhood in Post-Communist Poland. Future Human Image, 10, pp. 112-122. DOI: $10.29202 /$ fhi $/ 10 / 12$.

18. Kieliszek, Z., 2018. National Identity as an Important Topic of the Research of the Man in the Future: "Opening" the Potential of the Fichtean Concept of National Identity. Philosophy and Cosmology, 20, pp. 83-91. DOI: 10.29202/phil-cosm/20/7.

\section{Особливості менеджменту сучасними аналітичними центрами}

\section{І. І. Петренко, Г. М. Малкіна, В. В. Колюх}

Київський національний університет імені Тараса Шевченка, м. Київ, Україна, e-mail: i.petrenko.knu@gmail.com

Мета. Полягає в пошуку причин незначного впливу українських think tank на розвиток державного устрою України, а також у розробці нової стратегії менеджменту українських think tank для підвищення їх значущості у формуванні політичного мислення та державної політики України.

Методика. Автори використовували системноструктурний, структурно-функціональний метод, а також методи порівняння, аналізу, синтезу та експертної оцінки.

Результати. Автори розглянули розвиток think tank в історії світової культури й виявили три головні особливості: 1) вплив think tank на політичне мислення й державну політику здійснюється опосередковано, через осіб, які приймають політичні рішення; 2) менеджмент think tank - це вміння працювати з обдарованими людьми, які генерують політичні інноваціï; 3) менеджмент think tank - це найвища досконалість політики підприємництва, що дозволяє втілювати політичні інновації в державну політику. Автори розглянули менеджмент українських think tank і встановили його невідповідність світовим стандартам. Менеджмент українських think tank спеціалізується, головним чином, на аналізі проблем і рекомендаціях щодо їх вирішення, тоді як менеджмент провідних світових think tank націлений на втілення політичних інновацій у політичні рішення. Автори запропонували нову стратегію менеджменту українських think tank, що заснована на переосмисленні ставлення до: 1) людських ресурсів; 2) матеріальних ресурсів; 3) інформаційних ресурсів; 4) репутаційних ресурсів.

Наукова новизна. Автори довели невідповідність менеджменту українських think tank стандартам провідних think tank світу. Українські think tank poблять акцент на аналізі проблеми, тоді як менеджмент провідних світових think tank втілює політичні інновації в політичні рішення. Автори розробили нову стратегію менеджменту українських think tank. Вона заснована на переосмисленні чотирьох ключових ресурсів: 1) людського; 2) матеріального; 3) інформаційного; 4) репутаційного.

Практична значимість. Використання результатів, отриманих у ході дослідження, підвищить ефективність українських think tanks. Автори вважають, що нова стратегія менеджменту приверне в українські think tanks обдарованих учених, які здатні генерувати інноваційні політичні стратегіi, а також обдарованих управлінців, які донесуть політичні інновації до чиновників, політиків і політичних партій. Менеджмент, спрямований на генерацію політичних інновацій і їх втілення в державну політику, дозволить українським think tanks зайняти важливу нішу в розвитку української державності.

Ключові слова: think tanks, менеджмент, українська політична еліта, політичне мислення

\section{Особенности менеджмента современными аналитическими центрами}

\section{И. И. Петренко, А. Н. Малкина, В. В. Колюх}

Киевский национальный университет имени Тараса Шевченко, г. Киев, Украина, e-mail: i.petrenko.knu@ gmail.com 
Цель. Заключается в поиске причин незначительного влияния украинских think tank на развитие государственного устройства Украины, а также в разработке новой стратегии менеджмента украинских think tank для повышения их значимости в формировании политического мышления и государственной политики Украины.

Методика. Авторы использовали системноструктурный, структурно-функциональный метод, а также методы сравнения, анализа, синтеза и экспертной оценки.

Результаты. Авторы рассмотрели развитие think tank в истории мировой культуры и обнаружили три главные особенности: 1) влияние think tank на политическое мышление и государственную политику осуществляется опосредованно, через лиц, которые принимают политические решения; 2) менеджмент think tank - это умение работать с одаренными людьми, которые генерируют политические инновации (policy innovation); 3) менеджмент think tank - это наивысшее совершенство политики предпринимательства (policy entrepreneurship), которая позволяет воплощать политические инновации в государственную политику. Авторы рассмотрели менеджмент украинских think tank и установили его несоответствие мировым стандартам. Менеджмент украинских think tank специализируется, главным образом, на анализе проблем и рекомендациях по их решению, тогда как менеджмент ведущих мировых think tank нацелен на воплощение политических инноваций в политические решения. Авторы предложили новую стратегию менеджмента украинских think tank, которая основана на переосмыслении отношения к: 1) че- ловеческим ресурсам; 2) материальным ресурсам; 3) информационным ресурсам; 4) репутационным ресурсам.

Научная новизна. Авторы доказали несоответствие менеджмента украинских think tank стандартам ведущих think tank мира. Украинские think tank делают акцент на анализе проблемы, тогда как менеджмент ведущих мировых think tank воплощает политические инновации в политические решения. Авторы разработали новую стратегию менеджмента украинских think tank. Она основана на переосмыслении четырех ключевых ресурсов: 1) человеческого; 2) материального; 3) информационного; 4) репутационного.

Практическая значимость. Использование результатов, полученных в ходе исследования, повысит эффективность украинских think tanks. Авторы считают, что новая стратегия менеджмента привлечет в украинские think tanks одаренных ученых, которые способны генерировать инновационные политические стратегии, а также одаренных управленцев, которые донесут политические инновации до чиновников, политиков и политических партий. Менеджмент направленный на генерацию политических инноваций и их воплощение в государственную политику, позволит украинским think tanks занять важную нишу в развитии украинской государственности.

Ключевые слова: think tanks, менеджмент, украинская политическая элита, политическое мышление

Рекомендовано до публікації докт. політ. наук В.П.Горбатенком. Дата надходження рукопису 17.12.17. 